GRASAS Y ACEITES 66 (4)

October-December 2015, e101

ISSN-L: 0017-3495

doi: http://dx.doi.org/10.3989/gya.0233151

\title{
Characteristics and fatty acid composition of milk fat from Saudi Aradi goat
}

\author{
H.M. Sbihi ${ }^{\mathrm{a}, \bowtie}$, I.A. Nehdi ${ }^{\mathrm{a}}$, C.P. Tan ${ }^{\mathrm{b}}$ and S.I. Al-Resayes ${ }^{\mathrm{a}}$ \\ ${ }^{a}$ King Saud University, College of Science, Chemistry Department, P.O. BOX 2454, Riyadh 1145, Saudi Arabia \\ ${ }^{b}$ Department of Food Technology, Faculty of Food Science and Technology, \\ Universiti Putra Malaysia, 43400 UPM, Serdang, Selangor, Malaysia \\ Corresponding author: hmsbihi@ksu.edu.sa
}

Submitted: 04 February 2015; Accepted: 26 May 2015

SUMMARY: Goat milk is the second most prevalent edible milk in Saudi Arabia and is one of the most prominently produced milks in the world. Few studies have focused on the physicochemical properties of goat milk fat (GMF). Samples of Saudi Aradi goat milk were obtained during the spring dairy season to determine the physicochemical characteristics and fatty acid composition of the GMF. The physicochemical properties of Saudi Aradi GMF were as follows: iodine value, $23.2 \mathrm{~g}$ of $\mathrm{I}_{2} \cdot 100 \mathrm{~g}^{-1}$ of fat; saponification value, $213.2 \mathrm{mg} \mathrm{KOH} \cdot \mathrm{g}^{-1}$ of fat; refractive index $\left(25{ }^{\circ} \mathrm{C}\right), 1.4583$; unsaponifiable matter, $0.54 \%$; acidity, $0.52 \%$; and peroxide value, $2.07 \mathrm{meq} \mathrm{O}_{2} \cdot \mathrm{kg}^{-1}$ of fat. $\alpha$-Tocopherol was the major tocol $(70.9 \%)$, followed by $\beta$-tocopherol $(22.02 \%)$. GMF had significant contents of polyunsaturated fatty acid (FA) (6.16\%), conjugated linolenic acid ( $0.36 \%)$, saturated FA $(67.04 \%)$ and branched FA $(1.98 \%)$. The thermal profiles of the Saudi Aradi GMF samples were examined using a thermal gravimetric analysis (TGA) and differential scanning calorimetry (DSC). Saudi Aradi GMF showed some absorbance in the UV-C range. This study demonstrated that the milk fat from the Saudi goat has physically and chemically favorable properties, as well as good nutritional properties, as a source of essential fatty acids and fat-soluble vitamin $\mathrm{E}$.

KEYWORDS: Fatty acids; Goat milk fat; Physicochemical properties; Thermal analysis

RESUMEN: Características y composición en ácidos grasos de la grasa láctea de cabras de Arabia Saudí. La leche de cabra es la segunda leche comestible predominante en Arabia Saudí y es una de las leches de mayor producción en el mundo. Pocos estudios se han centrado en las propiedades físico-químicas de la grasa de leche de cabra (GLC). Muestras de leche de cabra Arabia Saudí fueron obtenidas durante la temporada de mayor producción lechera, durante la primavera, y se determinaron sus características físico-químicas y la composición de ácidos grasos de la GLC. Las propiedades fisicoquímicas determinadas de la GLC de Arabia Aradi fueron las siguientes: índice de yodo, 23,2 $\mathrm{g} \mathrm{de}_{2} \cdot 100 \mathrm{~g}^{-1}$ de grasa; índice de saponificación: $213,2 \mathrm{mg}$ de $\mathrm{KOH} \cdot \mathrm{g}^{-1}$ de grasa; índice de refracción a $25{ }^{\circ} \mathrm{C}: 1.4583$; insaponificable: $0,54 \%$; acidez: $0,52 \%$; y el índice de peróxidos, $2,07 \mathrm{meq} \mathrm{O}_{2} \cdot \mathrm{kg}^{-1}$ de grasa. $\alpha$-tocoferol fue el principal tocol $(70,9 \%$, seguido de $\beta$ - tocoferol $(22,02 \%)$. La GLC tiene un contenido significativo de ácidos grasos poliinsaturados (FA) $(6,16 \%)$, ácido linoleico conjugado $(0,36 \%)$, ácidos grasos saturados $(67,04 \%)$ y ácidos grasos ramificados $(1,98 \%)$. Los perfiles térmicos de las muestras de GLC de Arabia Aradi fueron examinados utilizando análisis térmico gravimétrico (ATG) y calorimetría diferencial de barrido (CDB). La GLC de Arabia Aradi mostró cierta absorbancia en el rango UV-C. Este estudio demostró que la grasa de la leche de la cabra de Arabia tiene propiedades física y químicamente favorables, así como buenas propiedades nutricionales, como fuente de ácidos grasos esenciales y vitamina E liposoluble.

PALABRAS CLAVE: Ácidos grasos; Análisis térmico; Grasa de leche de cabra; Propiedades fisicoquímicas 
Citation/Cómo citar este artículo: Sbihi HM, Nehdi IA, Tan CP, Al-Resayes SI. 2015. Characteristics and fatty acid composition of milk fat from Saudi Aradi goat. Grasas Aceites 66 (4): e101. doi: http://dx.doi.org/10.3989/gya.0233151.

Copyright: (C) 2015 CSIC. This is an open-access article distributed under the terms of the Creative Commons Attribution-Non Commercial (by-nc) Spain 3.0 Licence.

\section{INTRODUCTION}

Goats were among the first farm animals to be domesticated. They are among the most important providers of essential foods in the form of meat and dairy products worldwide. Goats have been raised in various areas of the world and are well known for their high ability to adapt to tropical and subtropical regions, especially in the arid regions. In Saudi Arabia, where the climate is suitable for goats, the number of these animals is approximately 2.2 million (Aziz and Al-Hur, 2013). Najdi, Harri and Aradi goat breeds are among the most widely spread goat breeds in Saudi Arabia (Sabir et al., 2013) and Aradi goats are the most desirable goats and are widely existing in the western region and the southern part of the Kingdom.

Goat milk is considered a useful alternative for infants and adults who are sensitive or allergic to cow milk (Park, 1994; Fabre, 1997; Sabbah et al., 1997). Goat milk is also recognized for its high therapeutic and nutritional value because of its relatively elevated levels of caproic, caprylic, capric and mediumchain fatty acids, which have been used for the treatment of a variety of malabsorption syndromes (Park, 1994; Alférez et al., 2001), and because of its smaller fat globule size, which makes goat milk more easily digestible than cow milk (Jandal, 1996).

Saudi goat milk is drunk directly after boiling, or made into yogurt, or made into ghee, or cheese. In modern industry, goat milk is converted to several economic products with high nutritional value, including pasteurized milk, yoghurt, cheese, cream, butter and milk powder.

Fat is one of the most important components in the technological and nutritional quality of goat milk. Goat milk fat is more digestible (Alferez et al., 2001; Haenlein, 2001) and may be considered an excellent source of energy for use in various metabolic processes (Boza and Sanz Sampelayo, 1997; Ceballos et al., 2009), even for combating metabolic diseases (Ceballos et al., 2009).

Shingfield et al. (2008) reported that lipid and fatty acid compounds are deemed to be positive or negative factors with respect to the health of human consumers. This consideration supports the interest in studying the characteristics and fatty acid composition of goat milk fat.

The present study aimed at evaluating the physicochemical characteristics of Saudi Aradi goat milk fat, which is widely used in the Kingdom of Saudi Arabia. A detailed analysis of its important parameters, such as iodine value, saponification value, peroxide value, kinematic viscosity, specific gravity, and acid value, wa conducted. Furthermore, a study of the thermal stability and the UV/visible spectrum of the goat milk fat was conducted. These results may allow a better understanding of this milk fat and thus the possible uses of it.

\section{MATERIALS AND METHODS}

\subsection{Milk collection and sample preparation}

Raw goat milk was obtained in April from a local farm in Qurayyat, Al Jawf province, northern Saudi Arabia. The collected goat milk used in the present study is a mixture of the milks produced by 10 Saudi Aradi goats during their lactating season (after their first kidding). The milk yields for the Aaradi goats during lactation were $1000 \pm 100 \mathrm{~g} \cdot \mathrm{day}^{-1}$. The goats were kept under identical conditions of feeding and management. They were ear-tagged and housed in a semi-shaded, open-front barn and fed on a commercial concentrate and alfalfa hay. The amounts of concentrate and alfalfa hay were calculated according to the nutritional requirements for goats depending on the animals' ages and production status (NRC, 1985). Water, straw, salt and minerals supplemented in the blocks were freely available to all goats. To perform an analysis of the fatty acid composition of the Aradi goat milk, three milk samples were collected during two weeks, at three different times from the end of March until mid-April. Each sample contained three liters of goat milk. The milk samples were centrifuged at $1000 \mathrm{rpm}$ for a duration of four minutes, and afterwards, the floating globules were collected. This portion consisted of fat matter appropriately extracted from raw goat milk. The resulting fat was melted at $70{ }^{\circ} \mathrm{C}$ and filtered through a Whatman filter paper no. 2(W\&R Balston Ltd., England). The yellow extracted fat was stored at $-20^{\circ} \mathrm{C}$ during the experimental period.

\subsection{Analytical methods}

The analyses were conducted in triplicate. The values of different parameters were expressed as the means \pm standard deviation ( $\mathrm{x} \pm$ S.D. $)$.

\subsubsection{Physicochemical properties}

The International Organization for Standardization (ISO) standards were used to determine the peroxide value (ISO, 2001), acidity (the percentage of free fatty 
acids was calculated as the oleic acid) (ISO, 1996), saponification value (ISO, 2002) and amount of unsaponified matter (ISO, 2000) of the GMF. The refractive index of the GMF was determined using an Abbe refractometer (Bellingham and Stanley, Ltd., Kent, England). The kinematic viscosity was determined using an Ubbelohde-type size 2 viscometer (Koehler, Bohemia, New York, USA). The melting point of the GMF was measured using a Stuart SMP 11 melting point apparatus (Bibby Scientific, Staffordshire, UK). UV spectra of the $0.01 \%$, $1 \%$, and $10 \%(\mathrm{v} / \mathrm{v})$ fats in hexane were measured at 200-290, 290-400, and 400-800 nm, respectively, using a UVmini-1240 spectrophotometer (Shimadzu, Kyoto, Japan). The theoretical iodine value was calculated using the average molecular weight and the absolute number of double bonds obtained from the ${ }^{1} \mathrm{H}$ NMR spectrum (Nehdi et al., 2013). The ${ }^{1} \mathrm{H}$ NMR analyses were performed using a JEOL ESC $400 \mathrm{MHz}$ spectrometer equipped with $5-\mathrm{mm} \mathrm{BBO}$ probes at $7.05 \mathrm{~T}$. Deuterated chloroform $\left(\mathrm{CDCl}_{3}\right)$ and trimethylsilane (TMS) were used as the solvent and internal standard, respectively. Chlorophyll and carotenoid contents were determined spectrophotometrically using a method described by Allalout et al. (2009).

\subsubsection{Infrared analysis}

The infrared spectra were recorded on a Bruker Tensor 27 FT-IR spectrometer interfaced to a personal computer operating under Opus 6.5 Software (Bruker, Rheinstetten, Germany). The spectrum was obtained through the horizontal attenuated total reflectance (ATR) technique using a removable $\mathrm{ZnSe}$ crystal. The samples were dissolved in $\mathrm{CCl}_{4}$, and the spectrum was obtained over 64 scans with a spectrum resolution of $4 \mathrm{~cm}^{-1}$. Three spectra in the region of $4000-400 \mathrm{~cm}^{-1}$ were collected, and the averaged spectrum was plotted as a percent transmittance curve versus wavenumbers.

The assignments of bands to a specific functional group vibration mode were performed by comparison with previous studies of seed oils.

\subsubsection{Fatty acid composition}

The analysis of the total fatty acid composition of GMF was performed using standard techniques and reagents. The GMF samples were saponified and methylated, as reported by Nehdi et al. (2013). Fatty acid methyl esters were obtained by adding $1 \mathrm{~mL}$ hexane and $200 \mu \mathrm{L}$ of $2 \mathrm{M}$ sodium methoxide to $40 \mathrm{mg}$ oil. The mixture was heated in a water bath at $50{ }^{\circ} \mathrm{C}$ for a few seconds, and then $200 \mu \mathrm{L}$ of $2 \mathrm{M}$ $\mathrm{HCl}$ were added. A $1-\mu \mathrm{L}$ aliquot of the top layer was used for analysis. The identification and quantification of fatty acids were performed using a gas chromatography-mass spectrometry (GCMS-QP2010, Shimadzu, Kyoto, Japan) Ultra instrument and an
Rtx-1 column $(30 \mathrm{~m} \times 0.25 \mathrm{~mm}$ i.d., $0.25 \mu \mathrm{m}$ film thickness) with helium as the carrier gas at a flow rate of $1.41 \mathrm{~mL} \cdot \mathrm{min}^{-1}$. The oven temperature was increased from 150 to $180^{\circ} \mathrm{C}$ at a rate of $15^{\circ} \mathrm{C} \cdot \mathrm{min}^{-1}$, followed by an increase to $210^{\circ} \mathrm{C}$ at $1^{\circ} \mathrm{C} \cdot \mathrm{min}^{-1}$. The temperatures of the injector and detector were $220^{\circ} \mathrm{C}$ and $275^{\circ} \mathrm{C}$, respectively. For GC/MS detection, an electron ionization system with an ionization energy of $70 \mathrm{eV}$ was used. The ion source temperature was $230{ }^{\circ} \mathrm{C}$, and the interface temperature was $280{ }^{\circ} \mathrm{C}$. The components were identified by comparing their relative retention times and mass spectra with those of standards (main components) using the Wiley 8 library data of the main system.

The relative percentages of the individual fatty acids were calculated based on the ratios of the peak areas of the fatty acid species to the total peak area of all the fatty acids in the fat sample.

\subsubsection{Tocol composition}

The tocols in the GMF were analyzed via highperformance liquid chromatography (HPLC) according to the ISO, 2006 standard. The HPLC system was equipped with a Shimadzu LC-20AT pump (Shimadzu, Kyoto, Japan), a Shimadzu-RF 20A fluorescence detector (at excitation and emission wavelengths of 295 and $330 \mathrm{~nm}$, respectively), and a Rheodine 7725(i) manual injector (Rohnert Park, USA). The tocols were separated on a normal-phase column (Hypersil silica, $15 \mathrm{~cm} \times 3 \mathrm{~mm}$ I.D., 3- $\mu \mathrm{m}$ particle size; Thermo scientific) with a mobile-phase flow rate of $0.5 \mathrm{~mL} \cdot \mathrm{min}^{-1}$ at ambient temperature. The mobile phase was a mixture of n-hexane:isopropanol (99.5:0.5) (v/v). The data were integrated and analyzed using Shimadzu's LC solution software. A $0.5 \mathrm{~g}$ GMF sample was diluted with $25 \mathrm{ml}$ of hexane, and $20 \mu \mathrm{L}$ of the diluted sample were injected into the column. A mixture of standard alpha, beta, gamma, and delta tocopherol and tocotrienol isomers (Sigma Chemical Co., St. Louis, Mo., U.S.A.) was dissolved in hexane at $2 \mu \mathrm{g} \cdot \mathrm{mL}^{-1}$, and aliquots were used to identify and quantify the peaks. The tocopherol quantity in the extracts was calculated in mg tocopherols per $100 \mathrm{~g}$ fat sample.

\subsubsection{Thermal analysis}

The thermal properties were evaluated using a thermal balance (TGA-50, Shimadzu, Kyoto, Japan) under an air atmosphere $\left(100 \mathrm{~mL} \cdot \mathrm{min}^{-1}\right)$ using alumina crucibles in non-isothermal conditions. The thermogravimetric (TG) and first derivative thermogravimetric (DTG) curves were obtained using a sample mass of $5.0 \pm 0.5 \mathrm{mg}$, heating rate of $10^{\circ} \mathrm{C} \cdot \mathrm{min}^{-1}$, and temperature range of $25-600{ }^{\circ} \mathrm{C}$. The Shimadzu TA-60 WS (2.20) software was used to analyze the data from the three independent measurements and to obtain the TG/DTG curves. 


\subsubsection{Differential scanning calorimetry}

DSC curves were measured with a Shimadzu DSC-60 differential scanning calorimeter (Shimadzu, Kyoto, Japan) that had been previously calibrated with indium. Samples weighing between 10 and $12 \mathrm{mg}$ were packed in aluminum DSC pans before being placed in the DSC cell. The samples were subjected to the following temperature program: $100{ }^{\circ} \mathrm{C}$ isotherm for $1 \mathrm{~min}$, cooled to $-100^{\circ} \mathrm{C}$ at a rate of $20^{\circ} \mathrm{C} \cdot \mathrm{min}^{-1}$, and held for $1 \mathrm{~min}$. The same sample was then heated from $-100{ }^{\circ} \mathrm{C}$ to $100^{\circ} \mathrm{C}$ at the same rate. The samples were cooled and heated under a constant flow of nitrogen (99.9999\% purity).

\section{RESULTS AND DISCUSSION}

\subsection{The physicochemical properties of GMF}

The results of the physico-chemical analysis of the Saudi Aradi GMF are presented in Table 1. The fat content of the studied goat milk was approximately $4.2 \%(\mathrm{w} / \mathrm{w})$. The studied GMF presents a yellow color. The color of GMF is mainly related to the presence of chlorophylls and carotenoids, which also provide oxidation protection in the dark. As shown in Table 1, chlorophylls and carotenoids comprised 2.88 and $1.31 \mathrm{mg} \cdot \mathrm{kg}^{-1}$ of the GMF, respectively.

TABLE 1. Physicochemical properties, chlorophylls, carotenoids and Tocopherol compositions of Saudi Aradi goat milk fat

\begin{tabular}{|c|c|c|}
\hline Physicochemical parameters & Unit & Goat milk fat \\
\hline Color & & yellow \\
\hline State at ambient temperature & & Solid \\
\hline Melting point & ${ }^{\circ} \mathrm{C}$ & $35-36$ \\
\hline Milk fat content & $\%(w / w)$ & $4.2 \pm 0.2$ \\
\hline Refractive index $\left(40^{\circ} \mathrm{C}\right)$ & & $1.4583 \pm 0.06$ \\
\hline Kinematic viscosity $\left(40^{\circ} \mathrm{C}\right)$ & $\mathrm{mm}^{2} \cdot \mathrm{s}^{-1}$ & $25.8 \pm 0.52$ \\
\hline Unsaponifiable matter & $(\%, w / w)$ & $0.54 \pm 0.02$ \\
\hline Saponification value & $\mathrm{mg} \mathrm{KOH} \cdot \mathrm{g}^{-1}$ fat & $213.2 \pm 2.6$ \\
\hline Peroxide value & meq $\mathrm{O}_{2} \cdot \mathrm{kg}^{-1}$ fat & $2.07 \pm 0.1$ \\
\hline Free fatty acid & as oleic $\%$ & $0.52 \pm 0.02$ \\
\hline Acid value & $\mathrm{mg} \mathrm{KOH} \cdot \mathrm{g}^{-1}$ & $1.04 \pm 0.04$ \\
\hline Iodine number & $\mathrm{g} \cdot 100 \mathrm{~g}^{-1}$ fat & 23.2 \\
\hline Molecular weight & $\mathrm{g} \cdot \mathrm{mol}^{-1}$ & 789.36 \\
\hline Chlorophylls & $\mathrm{mg} \cdot \mathrm{kg}^{-1}$ & $2.88 \pm 0.09$ \\
\hline Carotenoids & $\mathrm{mg} \cdot \mathrm{kg}^{-1}$ & $1.31 \pm 0.06$ \\
\hline Tocopherols & $\mathrm{mg} \cdot 100 \mathrm{~g}^{-1}$ & $\%$ \\
\hline$\alpha$ - Tocopherol & $2.80 \pm 0.3$ & $70.9 \pm 0.9$ \\
\hline$\gamma$ - Tocopherol & $0.87 \pm 0.2$ & $22.02 \pm 0.27$ \\
\hline$\delta$ - Tocopherol & $0.14 \pm 0.01$ & $3.58 \pm 0.08$ \\
\hline$\delta$ - Tocotrienol & $0.14 \pm 0.01$ & $3.48 \pm 0.08$ \\
\hline
\end{tabular}

The iodine value $\left(23.2 \mathrm{~g}\right.$ of $\mathrm{I}_{2} \cdot 100 \mathrm{~g}^{-1}$ fat $)$ of the GMF was low due to its high content of saturated fatty acids $(67.04 \%)$; it was low compared to buffalo milk fat (34-37) (Abd El-Aziz et al., 2012) but slightly higher than a previous value of goat milk (19-20) (Park et al., 2007). The saponification value of GMF was 213.2. This value is directly related to the mean molecular mass. The high saponification value is due to the presence of short- and medium-chain fatty acids (Table 2). The peroxide value of GMF was $2.07 \mathrm{meq} \mathrm{O}_{2} \cdot \mathrm{kg}^{-1}$. Generally, fats with peroxide values of less than $10 \mathrm{meq} \mathrm{O}_{2} \cdot \mathrm{kg}^{-1}$ are considered safe for human consumption. The content of free fatty acids as a percentage of oleic acid was $0.52 \%$. The kinematic viscosity of the GMF was $25.8 \mathrm{~mm}^{2} \cdot \mathrm{s}^{-1}$ and was lower compared to the kinematic viscosity of butter fat $\left(42 \mathrm{~mm}^{2} \cdot \mathrm{s}^{-1} ; 43{ }^{\circ} \mathrm{C}\right)$. The refractive index of GMF was 1.4583 , which is approximately the same value found by Park et al. (2007) for goat milk.

Regarding vitamin E, four tocopherol isomers were identified and quantified. The mean levels of alpha-, delta-, and gamma-tocopherols and deltatocotrienol for the samples were 2.8, 0.87, 0.14 and $0.14 \mathrm{mg} \cdot 100 \mathrm{~g}^{-1}$ of GMF, respectively (Table 1). These values were higher than those found by Raynal-Ljutovac et al. (2008).

\subsection{Fatty acid composition}

The fatty acid composition of Saudi Aradi goat milk fat (GMF) is shown in Table 2. The results showed that GMF contained a lower percentage of saturated fatty acid (SFA) (67.15\%). Alonso et al. (1999) reported that GMF contained $72.23 \%$ of SFA (Table 2). In human dietary trials, the consumption of novel milk products with reduced SFA proportions significantly lowered the total plasma cholesterol, and most of this decrease was noted in the low density lipoprotein cholesterol fraction (Cattaneo et al., 2006). Saudi Aradi GMF contained a high amount of monounsaturated fatty acid (MUFA) $(26.78 \%)$ and some polyunsaturated fatty acid (PUFA) (6.16\%). MUFA and PUFA are useful in the prevention of cardiovascular diseases and some inflammatory disorders (Blasi et al., 2008). Saudi GMF appears to be more favorable for human health than other milk fats. Caproic acid (C6:0) was the most abundant (1.29\%) in the GMF samples compared with other shortchain fatty aicds (SCFAs). Capric acid (C10:0) was the main $(5.97 \%)$ medium-chain fatty acid (MCFA) (Table 2). As in all GMF, palmitic acid (C16:0) was the most abundant SFA $(31.7 \%)$, followed by myristic acid (C14:0; 9.04\%) and stearic acid (C18:0; $8.81 \%$ ). A lower proportion of myristic acid in milk fat appears to be favorable for human health because of its negative role in atherosclerosis (Pfeuffer and Schrezenemeir, 2000). Among the MUFAs, oleic acid (C18:1c9) showed a significantly higher content 
TABLE 2. The fatty acid profile of goat milk fat ( $\%$ of total fatty acids) from Saudi and Spain

\begin{tabular}{|c|c|c|}
\hline & GMF (Saudi) & GMF (Spain) ${ }^{\mathrm{a}}$ \\
\hline $\mathrm{C} 4: 0$ & $1.2 \pm 0.06$ & 2.18 \\
\hline C6:0 & $1.29 \pm 0.06$ & 2.39 \\
\hline $\mathrm{C} 8: 0$ & $1.56 \pm 0.07$ & 2.73 \\
\hline C9:0 & $0.07 \pm 0.01$ & $\mathrm{Nd}$ \\
\hline $\mathrm{C} 10: 1$ & $1.66 \pm 0.08$ & 0.24 \\
\hline C10:0 & $5.97 \pm 0.3$ & 9.97 \\
\hline C11:0 & $0.12 \pm 0.01$ & $\mathrm{Nd}$ \\
\hline C12:1 & $0.66 \pm 0.03$ & 0.19 \\
\hline C12:0 & $2.77 \pm 0.14$ & 4.99 \\
\hline $\mathrm{C} 13: 0$ & $0.12 \pm 0.01$ & 0.15 \\
\hline $\mathrm{C} 14: 1 c 9$ & $0.14 \pm 0.01$ & 0.18 \\
\hline C14:0 & $9.04 \pm 0.45$ & 9.81 \\
\hline anteiso-C15:0 & $0.12 \pm 0.01$ & 0.21 \\
\hline iso-C15:0 & $0.37 \pm 0.02$ & 0.13 \\
\hline C15:0 & $1.04 \pm 0.05$ & 0.71 \\
\hline iso-C16:0 & $0.29 \pm 0.01$ & 0.24 \\
\hline $\mathrm{C} 16: 1 t 7$ & $0.28 \pm 0.01$ & 1.59 \\
\hline $\mathrm{C} 16: 1 c 9$ & $0.82 \pm 0.04$ & \\
\hline $\mathrm{C} 16: 1 t 11$ & $0.2 \pm 0.01$ & \\
\hline $\mathrm{C} 16: 0$ & $31.7 \pm 0.8$ & 28.2 \\
\hline anteiso-C17:0 & $0.33 \pm 0.02$ & 0.42 \\
\hline iso-C17:0 & $0.87 \pm 0.04$ & 0.34 \\
\hline $\mathrm{C} 17: 0$ & $0.63 \pm 0.03$ & 0.72 \\
\hline $\mathrm{C} 18: 2 c 9, c 12$ & $3.73 \pm 0.2$ & 3.19 \\
\hline $\mathrm{C} 18: 3 c 9, c 12, c 15$ & $1.87 \pm 0.09$ & 0.42 \\
\hline $\mathrm{C} 18: 1 c 9$ & $18.53 \pm 0.46$ & 19.3 \\
\hline $\mathrm{C} 18: 1 t 8$ & $1.38 \pm 0.07$ & \\
\hline $\mathrm{C} 18: 1 t 9$ & $1.5 \pm 0.07$ & \\
\hline $\mathrm{C} 18: 1 t 10$ & $0.22 \pm 0.01$ & \\
\hline $\mathrm{C} 18: 1 t 11$ & $0.21 \pm 0.01$ & \\
\hline $\mathrm{C} 18: 1 t 12$ & $0.15 \pm 0.01$ & \\
\hline $\mathrm{C} 18: 0$ & $8.81 \pm 0.4$ & 8.88 \\
\hline $\mathrm{C} 18: 2 c 9,11 t$ & $0.33 \pm 0.02$ & 0.7 \\
\hline $\mathrm{C} 18: 2 t 9,11 t$ & $0.03 \pm 0.02$ & \\
\hline $\mathrm{C} 20: 4 c 5, c 8, c 11, c 14$ & $0.19 \pm 0.01$ & $\mathrm{Nd}$ \\
\hline $\mathrm{C} 20: 1 c 11$ & $1 \pm 0.04$ & $\mathrm{Nd}$ \\
\hline C20:0 & $0.63 \pm 0.03$ & 0.15 \\
\hline $\mathrm{C} 22: 1 c 13$ & $0.24 \pm 0.01$ & $\mathrm{Nd}$ \\
\hline $\mathrm{C} 22: 0$ & $0.07 \pm 0.01$ & $\mathrm{Nd}$ \\
\hline
\end{tabular}

${ }^{a}$ Park et al. (2007); Nd: not detected; SCFA: short chain fatty acids (C4-C6); MCFA: medium chain fatty acids (C8-C13); SFA: saturated fatty acids; MUFA: monounsaturated fatty acids; PUFA: polyunsaturated fatty acids; UFA: unsaturated fatty acids (PUFA+MUFA)

in GMF. CLA was also detected in GMF $(0.33 \%)$ and acts as a potent inhibitor of milk fat synthesis (De Veth et al., 2004). Branched-chain fatty acids were also quantified in Saudi GMF. Among them, the most important in quantitative terms were the iso- and anteiso-C15:0 (0.37\% and $0.12 \%)$, iso- and anteiso-C17:0 (0.87\% and $0.33 \%)$, and iso-C16:0 $(0.29 \%)$ (Table 1$)$, which confirm the findings of Alonso et al. (1999). Branched-chain fatty acids lend characteristic flavors to many dairy foods (Park et al., 2007). The trans fatty acids (TFA) content in GMF comprised $3.97 \%$ of the total fatty acids. The main TFA found was elaidic acid (C18:1t9).

\subsection{Infrared spectroscopy}

A representative spectrum of Saudi Aradi GMF is shown in Figure 1. The fat spectrum showed characteristic absorption bands for common triglycerides and fatty acids. The assignments of prominent peaks are given in Table 3. The FTIR spectrum of the GMF exhibited a characteristic band at $966 \mathrm{~cm}^{-1}$, corresponding to the $\mathrm{C}-\mathrm{H}$ out-of-plane deformation that is highly characteristic of unconjugated double bonds with a trans configuration. The distinctive band at $3470 \mathrm{~cm}^{-1}$ represents the overtone of the $\mathrm{C}=\mathrm{O}$ ester stretch (Henna Lu and Tan, 2009).

\subsection{Crystallization and melting behavior}

Figure 2 shows the DSC cooling and heating curves for Saudi Aradi GMF. The melting DSC curve exhibited two melting peaks at $15.4{ }^{\circ} \mathrm{C}$ and $38.7^{\circ} \mathrm{C}$, with enthalpies of $57.8 \mathrm{~J} \cdot \mathrm{g}^{-1}$ and $12.2 \mathrm{~J} \cdot \mathrm{g}^{-1}$, respectively. The large shoulder endothermic peak is attributed to the melting of triacylglycerol with a combination of unsaturated fatty acids, and SCFA and MCFA, while the small shoulder endothermic peak is attributed to the melting of triacylglycerols with a combination of long-chain SFAs, mainly C16:0 and C18:0, and MUFAs with a transconfiguration (Ten Grotenhuis et al., 1999). The melting enthalpy of GMF is slightly lower than that of anhydrous milk fat $\left(72.9 \mathrm{~J} \cdot \mathrm{g}^{-1}\right)$ due to its low SFA content (Sabariah et al., 1998). The cooling DSC curve (Figure 2) exhibited a crystallization peak at $1.9^{\circ} \mathrm{C}$ with an enthalpy of $-68.8 \mathrm{~J} \cdot \mathrm{g}^{-1}$. Cisneros et al. (2006) noted that the mixture of high- and low-melting milk fat fractions crystallized originally in the $\alpha$ polymorph but, due to the presence of a liquid phase, the transformation into the $\beta$ ' polymorph occurred rapidly. High-melting milk fat fractions $\left(10-25^{\circ} \mathrm{C}\right)$ are used in laminated pastries to promote layering and, in the chocolate industry, to inhibit fat blooming. Low-melting milk fat fractions $\left(35-50{ }^{\circ} \mathrm{C}\right)$ can be used for creaming applications in the biscuit and cheese industries (Gibon, 2006; Van Aken et al., 1999).

\subsection{Thermal analysis}

The thermogravimetric data (TGA) and first derivative data (DTG) of the GMF under a dry heating air atmosphere are presented in Figure 3. 


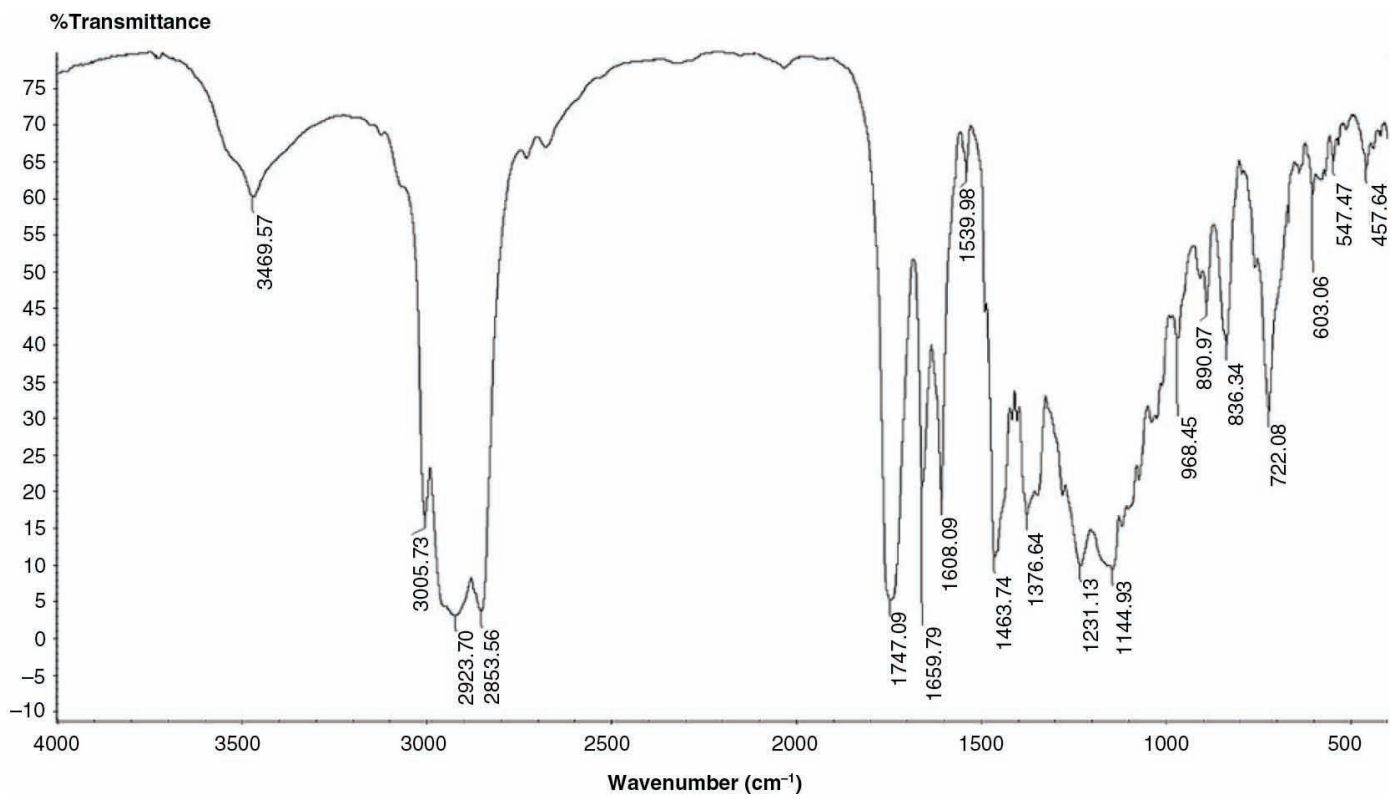

FIGURE 1. FT-IR spectrum of goat milk fat sample.

The thermogram indicated that the GMF was thermally stable up to $276.3^{\circ} \mathrm{C}$, with a mass loss of $5 \%$. A $90 \%$ mass loss occurred at $485.8^{\circ} \mathrm{C}$. The profiles of the TGA/DTG curves (Figure 3) showed three stages of decomposition for GMF, with a maximum at $316.5^{\circ} \mathrm{C}, 440{ }^{\circ} \mathrm{C}$ and at $541.3^{\circ} \mathrm{C}$.

Szabo et al. (2012) reported that the temperature range corresponding to the first stage could be attributed to the thermal decomposition of the unsaturated fatty acids, mainly C18:1, C18:2 and C18:3 and the SCFA (C4-C6). This stage is considered the most important and represents the initial phase of triacylglycerol degradation. In this phase, the oxidation of PUFAs occurs. The second and third phases represent the decomposition of the trans isomer fatty acids and SFAs, respectively.

TABLE 3. Fequencies, Functional Groups, Vibration Mode, and Intensity of GMF in FTIR spectra

\begin{tabular}{lllc}
\hline Wavenumber $\left(\mathbf{c m}^{-1}\right)$ & Functional group & \multicolumn{1}{c}{ Mode of vibration } & Intensity \\
\hline 3470 & $-\mathrm{C}=\mathrm{O}($ ester $)$ & Overtone & $\mathrm{W}$ \\
3009 & $=\mathrm{C}-\mathrm{H}($ cis- $)$ & Stretching & $\mathrm{M}$ \\
2952 & $-\mathrm{C}-\mathrm{H}\left(\mathrm{CH}_{3}\right)$ & Stretching (asymmetric) & $\mathrm{S}$ \\
2923 & $-\mathrm{C}-\mathrm{H}\left(\mathrm{CH}_{2}\right)$ & Stretching (asymmetric) & $\mathrm{S}$ \\
2853 & $-\mathrm{C}-\mathrm{H}\left(\mathrm{CH}_{2}\right)$ & Stretching (symmetric) & $\mathrm{S}$ \\
1747 & $-\mathrm{C}=\mathrm{O}(\mathrm{ester})$ & Stretching & $\mathrm{S}$ \\
1654 & $-\mathrm{C}=\mathrm{C}-($ cis $)$ & Stretching & $\mathrm{W}$ \\
1464 & $-\mathrm{C}-\mathrm{H}\left(\mathrm{CH}_{2}, \mathrm{CH}_{3}\right)$ & Bending (scissoring) & $\mathrm{S}$ \\
1417 & $=\mathrm{C}-\mathrm{H}($ cis $)$ & Bending (rocking) & $\mathrm{W}$ \\
1377 & $-\mathrm{C}-\mathrm{H}\left(\mathrm{CH}_{3}\right)$ & Bending (symmetric) & $\mathrm{M}$ \\
1239 & $-\mathrm{C}-\mathrm{O},-\mathrm{CH}_{2}-$ & Stretching, bending & $\mathrm{W}$ \\
1165 & $-\mathrm{C}-\mathrm{O},-\mathrm{CH}_{2}-$ & Stretching, bending & $\mathrm{S}$ \\
1113 & $-\mathrm{C}-\mathrm{O}$ & Stretching & $\mathrm{W}$ \\
967 & $-\mathrm{HC}=\mathrm{CH}-($ trans $)$ & Bending out of plane & $\mathrm{W}$ \\
722 & $-(\mathrm{CH}) n-$, & Bending (rocking) & $\mathrm{M}$ \\
& $-\mathrm{HC}=\mathrm{CH}-($ cis $)$ & Bending out of plane & \\
\hline
\end{tabular}

W: weak band; M: moderate band; S: strong band. 


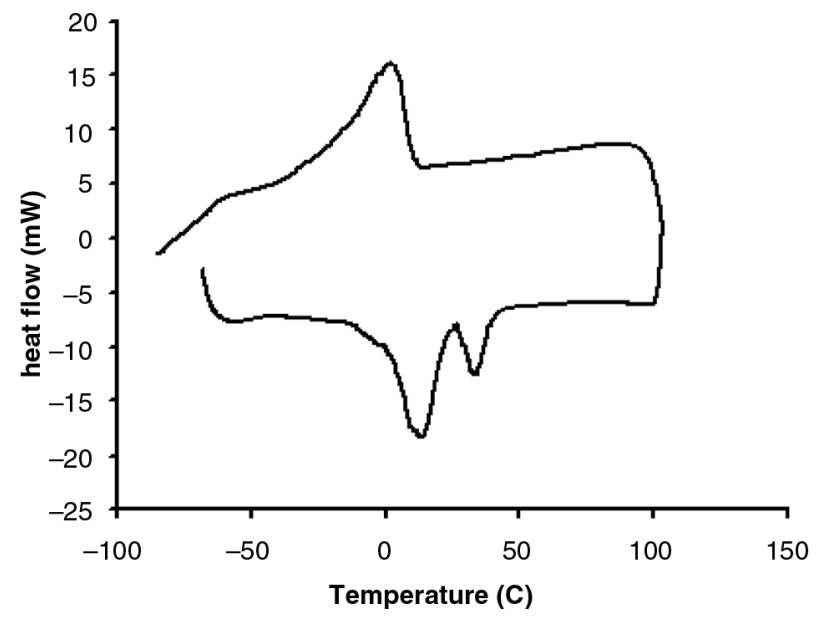

Figure 2. Heat flow of goat milk sample during heating and cooling process.

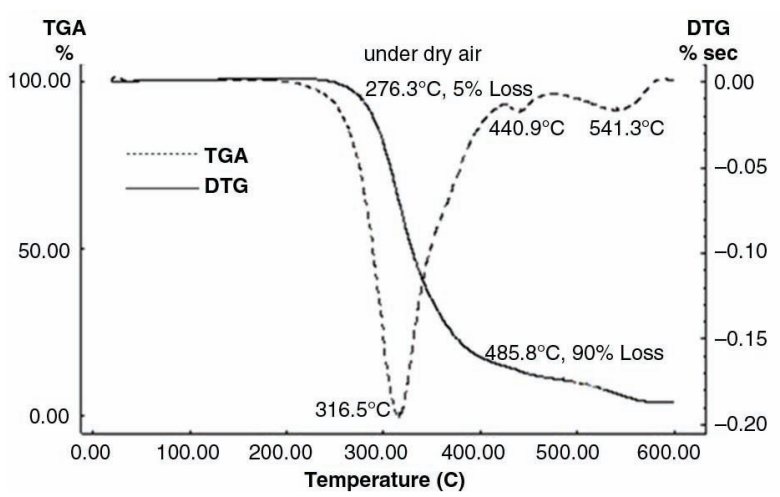

Figure 3. TGA/DTG curves of goat milk fat under dry air.

\subsection{UV/Visible spectrophotometry of the GMF}

Saudi Aradi GMF exhibits characteristic mediumintensity (1-1.5) absorbance peaks in the UV-C $(100-290 \mathrm{~nm})$ range between 200 and $230 \mathrm{~nm}$ (Figure 4). Thus, the GMF may be used in the formulation of sunscreens that provide protection against UV-C radiation (Fatnassi et al., 2009). GMF exhibited low-intensity absorbance $(0.4-0.65)$ in the $400-440 \mathrm{~nm}$ range (412 and $432 \mathrm{~nm}$ ), indicative of the corresponding carotenoid pigments, which explains the yellow color of the Saudi Aradi GMF. This yellow color, which includes carotenoids, is beneficial because it simulates the appearance of butter without the use of primary colorants, such as carotenes and annattos, which are commonly used in the oil and fat industries (Elleuch et al., 2007). The GMFs exhibited a slight absorbance in the visible region at $600-750 \mathrm{~nm}$, which is related to a low chlorophyll content. These data confirm the results presented in Table 1.
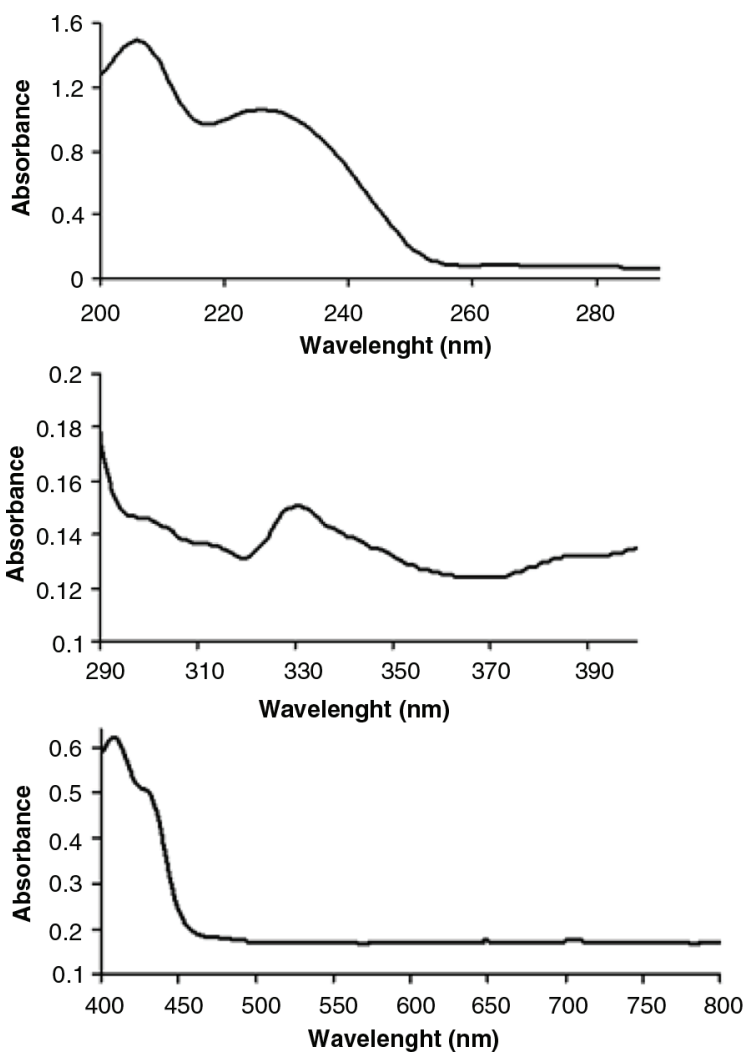

FIGURE 4. Ultra violet/visible spectra of goat milk fat (Figure derived from scans $(\lambda=200-290 \mathrm{~nm}$ ) of fat diluted 1:1000; from scans $(\lambda=290-400 \mathrm{~nm})$ of fat diluted $1: 100$ and from scans $(\lambda=400-800 \mathrm{~nm})$ of fat diluted $1: 10$, all in hexane.

\section{CONCLUSIONS}

According to the results obtained in the current study, Saudi Aradi GMF possesses favorable properties, both physically and chemically, and may have promising nutritional properties as a source of essential fatty acids and fat-soluble vitamins. These results may also be important for the production of milk fat products, such as butter and cheese, and potentially for the use of such cow milk fat substitutes.

This study achieved the primary step of evaluating the physicochemical properties of Saudi Arabia GMF and should be followed by further studies using a larger number of goats from different geographical regions in the Kingdom to determine the seasonal and feeding factors that affect the GMF composition. Goat milk fat also shows great potential for future use in skin care and cosmetics products.

\section{ACKNOWLEDGMENTS}

The authors would like to extend their sincere appreciation to the Deanship of Scientific Research at King Saud University for its funding of this research through the Research Group Project No RGP-VPP-243. 


\section{REFERENCES}

Abd El-Aziz M, Kholif SM, Morsy TA. 2012. Buffalo's milk composition and its fat properties as affected by feeding diet supplemented with flaxseed or fibrolytic enzymes in early lactation. Life Sci. 4, 19-25.

Alférez MJ, Barrionuevo M, López Aliaga I, Sanz-Sampelayo MR, Lisbona F, Robles JC, Campos MS. 2001. Digestive utilization of goat and cow milk fat in malabsorption syndrome. J. Dairy Res. 68, 451-461. http://dx.doi.org/10.1017/ S0022029901004903.

Allalout A, Krichène D, Methenni K, Taamalli A, Oueslati I, Daoud D, Zarrouk M. 2009. Characterization of virgin olive oil from Super Intensive Spanish and Greek. varieties grown in northern Tunisia. Sci. Hortic. 120, 77-83.

Alonso L, Fontecha J, Lozada L, Fraga MJ, Juárez M. 1999. Fatty acid composition of caprine milk: major, branchedchain, and trans fatty acids. J. Dairy Sci. 82, 878-884. http://dx.doi.org/10.3168/jds.S0022-0302(99)75306-3.

Aziz MMA, Al-Hur FS. 2013. Differentiation between three Saudi goat types using Size-free Canonical Discriminant Analysis. Emir. J. Food Agric. 25, 723-735.

Blasi F, Montesano D, De Angelis M, Maurizi A, Ventura F, Cossignani L, Simonetti MS, Damiani P. 2008. Results of stereospecific analysis of triacylglycerol fraction from donkey, cow, ewe, goat and buffalo milk. J. Food Compos. Anal. 21, 1-7. http://dx.doi.org/10.1016/j.jfca.2007.06.005.

Boza J, Sanz Sampelayo MR. 1997. Aspectos nutricionales de la leche de cabra. Anales de la Real Academia de Ciencias Veterinarias de Andalucía Oriental, 10, 109-139.

Cattaneo D, Dell'Orto V, Varisco G, Agazzi A, Savoini G. 2006. Enrichment in n-3 fatty acids of goat's colostrum milk by maternal fish oil supplementation. Small Ruminant Res. 64, 22-29. http://dx.doi.org/10.1016/j.smallrumres.2005.03.013.

Ceballos LS, Morales ER, Adarve GT, Castro JD, Martínez LP, Sanz-Sampelayo MR. 2009. Composition of goat and cow milk produced under similar conditions and analyzed by identical methodology. J. Food Compos. Anal. 22, 322-329. http://dx.doi.org/10.1016/j.jfca.2008.10.020.

De Veth MJ, Griinari JM, Pfeiffer AM, Bauman DE. 2004. Effect of CLA on milk fat synthesis in dairy cows: comparison of inhibition by methyl esters and free fatty acids, and relationships among studies. Lipids, 39, 365-372. http:// dx.doi.org/10.1007/s11745-004-1240-4.

Elleuch M, Besbes S, Roiseux O, Blecker C, Attia H. 2007. Quality characteristics of sesame seeds and by-products. Food Chem. 103, 641-650. http://dx.doi.org/10.1016/j. foodchem.2006.09.008.

Fabre A. 1997. Perspectives actuelles d'utilisation du lait de chèvre dans l'alimentation infantile. Proceedings, Colloque Intérêts Nutritionnel et Diététique du Lait de Chèvre . Inst. Nat. Rech. Agron. Publ., Paris, France, No. 81, pp. 123-126.

Fatnassi S, Nehdi I, Zarrouk H. 2009. Chemical composition and profile characteristics of Osage orange Maclura pomifera (Rafin.) Schneider seed and seed oil. Ind. Crops Prod. 29 , 1-8s. http://dx.doi.org/10.1016/j.indcrop.2008.04.013.

Gibon V. 2006. Fractionation of lipids for use in food. in Gunstone FD (Ed.) Modifying Lipids for Use in Food. Woodhead Publishing Ltd, Cambridge, England, pp. 201-233. http:// dx.doi.org/10.1533/9781845691684.2.201

Haenlein GF. 2001. Past, present, and future perspectives of small ruminant dairy research. J. Dairy Sci. 84, 2097-2115. http:// dx.doi.org/10.3168/jds.S0022-0302(01)74655-3.

Henna Lu FS, Tan PP. 2009. A Comparative study of storage stability in virgin coconut oil and extra virgin olive oil upon thermal treatment. Int. Food Res. J. 16, 343-354.

ISO, 1996. Animal and vegetable fats and oils-ISO 660: Determination of acid value and acidity. International Organisation for Standardisation.
ISO, 2000. Animal and vegetable fats and oils-ISO 3596: Determination of unsaponifiable matter-method using diethyl ether extraction. International Organisation for Standardisation.

ISO, 2001. Animal and vegetable fats and oils-ISO 3960: Determination of peroxide value. International Organisation for Standardisation.

ISO, 2002. Animal and vegetable fats and oils-ISO 3657: Determination of saponification value. International Organisation for Standardisation.

ISO, 2006. Animal and vegetable fats and oils-ISO 9936: Determination of tocopherol and tocotrienol contents by high-performance liquid chromatography. International Organisation for Standardisation.

Jandal JM. 1996. Comparative aspects of goat and sheep milk. Small Ruminant Res. 22, 177-185. http://dx.doi.org/10.1016/ S0921-4488(96)00880-2.

Nehdi IA, Sbihi H, Tan CP, Al-Resayes SI. 2013. Evaluation and characterisation of Citrullus colocynthis (L.) Schrad seed oil: Comparison with Helianthus annuus (sunflower) seed oil. Food Chem. 136, 348-353. http://dx.doi.org/10.1016/j. foodchem.2012.09.009.

NRC, 1985. "National Research Council. Ruminant nitrogen usage". Natl. Acad. Sci. Washington, DC.

Park YW. 1994. Hypo-allergenic and therapeutic significance of goat milk. Small Ruminant Res. 14, 151-159. http://dx.doi. org/10.1016/0921-4488(94)90105-8.

Park YW, Júarez M, Ramos M, Haenlein, GFW. 2007. Physicochemical characteristics of goat and sheep milk. Small Ruminant Res. 68, 88-113. http://dx.doi.org/10.1016/j. smallrumres.2006.09.015.

Pfeuffer M, Schrezenemeir J. 2000. Bioactive substances in milk with properties decreasing risk of cardiovascular disease. Br. J. Nutr. 84, 155-159. http://dx.doi.org/10.1017/ S0007114500002385.

Raynal-Ljutovac K, Lagriffoul G, Paccard P, Guillet I, Chilliard Y. 2008. Composition of goat and sheep milk products: an update. Small Ruminant Res. 79, 57-72. http://dx.doi. org/10.1016/j.smallrumres.2008.07.009.

Sabbah A, Hassoun S, Drouet M. 1997. L'allergie au lait de vache et sa substitution par le lait de chèvre. Proceedings, Colloque Intérêts Nutritionnel et Diététique du Lait de Chèvre. Inst. Nat. Rech. Agron. Publ., Paris, France, No 81, pp. 111-118.

Sabariah S, Ali ARM, Chong CL. 1998. Chemical and Physical Characteristics of Cocoa Butter Substitutes, Milk Fat and Malaysian Cocoa Butter Blends. J. Am. Oil Chem. Soc. 75, 905-910.

Sabir JSM, Sabry AM, Awad NS, Alaa AM, Mutawakil MHZ. 2013. Najdi, Harri and Aradi Saudi Goat Breeds Possess Genetic Variation Required for Genetic Improvement. World Appl. Sci. J. 26, 867-872.

Shingfield KJ, Chilliard Y, Toivonen V, Kairenius P, Givens DI. 2008. Trans fatty acids and bioactive lipids in ruminant milk. In B. Zsuzsanna (Ed.), Bioactive Components of Milk. Advances in Experimental Medicine and Biology. Springer, New York, pp. 3-65. http://dx.doi.org/10.1007/978-0-387-74087-4_1.

Szabo MR, Chambre D, Iditoiu C. 2012. TG/DTG/DTA for the oxidation behavior characterization of vegetable and animal fats. J. Therm. Anal. Calorim. 110, 281-285. http://dx.doi.org/ 10.1007/s10973-012-2253-2

Ten Grotenhuis E, van Aken GA, van Malssen KF, Schenk H. 1999. Polymorphism of milk fat studied by differential scanning calorimetry and real-time X-ray powder diffraction. $J$. Am. Oil Chem. Soc. 76, 1031-1039. http://dx.doi.org/10.1007/ s11746-999-0201-5.

Van Aken GA, Ten Grotenhuis E, Van Langevelde AJ, Schenk H. 1999. Composition and Crystallization of Milk Fat Fractions. J. Am. Oil Chem. Soc. 76, 1323-1331. http:// dx.doi.org/10.1007/s1 1746-999-0146-8 